\title{
The essence and mechanisms of environmental competence formation in students of natural science departments
}

\author{
Ruslana Romaniuk ${ }^{1 *}$, Olena Antonova², Oksana Sorochynska², Olga Tsurul' ${ }^{3}$, and Marina Sidorovich ${ }^{4}$ \\ ${ }^{1}$ Zhytomyr Ivan Franko State University, Faculty of Natural Science, 42 Pushkinska Str., Zhytomyr, 10008, Ukraine \\ ${ }^{2}$ Zhytomyr Ivan Franko State University, Educational and Research Institute of Pedagogics, 40 Velyka Berdychivska Str., Zhytomyr, \\ 10008, Ukraine \\ ${ }^{3}$ National Pedagogical Dragomanov University, Faculty of Natural and Geographical Education and Ecology, 9 Pyrohova, Str., Kyiv, \\ 01601, Ukraine \\ ${ }^{4}$ Kherson State University, Faculty of Biology, Geography and Ecology, 27 Universytetska Str., Kherson, 73003, Ukraine
}

\begin{abstract}
A comparative analysis of the ecological (environmental) educational component of the training in students of Natural Science Departments (Chemistry, Biology, Earth Sciences, Ecology) and future teachers of natural sciences has been carried out. The general and professional competences, program results of training, and applicants training educational programs on the example of several Ukrainian universities are analyzed. It is revealed that the formation of environmental competence is carried out by acquiring environmental education by means of interactive technologies, forms, and methods of organizing the educational process. The positive influence of students' involvement in research, environmental, ecological, and naturalistic work in extracurricular time on the formation of their environmental competence has been confirmed. The role of educational and industrial practices in the process of students' professional training and the formation of their environmental competence is emphasized.
\end{abstract}

\section{Introduction}

The strategy of the state ecological policy of Ukraine for the period till 2030 provides the following: introduction of the ecosystem approach in branch policy; integrated environmental management and implementation of international standards; taking into account the environmental component during economic activity; implementation of international environmental initiatives in Ukraine [2].

The document emphasizes the importance of maintaining air quality, reducing greenhouse gas emissions; protecting natural waters, forests, lands and soils; developing a national biosafety system; preserving the biological and landscape diversity, etc.

Ukraine has developed a national system of continuous sustainable development goals, which should become the foundation for overcoming imbalances in the economic, social, educational and environmental spheres; thus, it will contribute to the quality of life of present and future generations in harmony with the environment, as well as it will guarantee socio-economic and environmental stability, including a decent level of education and public health.

An important task today is the formation of ecological competence, environmental culture and environmental worldview of all segments of the population. In our opinion, the issue of formation of ecological competence of specialists of water quality analysis, forestry, agriculture, mining industry is especially urgent; nevertheless, specialists in Chemistry, Biology, Geography, Ecology; as well as teachers of natural sciences should also be covered, for the state of the environment will largely depend on the level of their ecological competence.

\section{Literature review}

The Second United Nations Conference on the Environment (Rio de Janeiro, 1992) declared the Agenda for the XXI Century program document, which for the first time set out the basic provisions for sustainable development. This is a kind of model of socio-economic development, in which the vital needs of the current generation are met in such a way that future generations are not affected by the depletion of natural resources and environmental degradation [3].

"Environment for Europe" congress took place in Kyiv in 2003, during which the member states of the United Nations Economic Commission for Europe (UNECE) have adopted the "Declaration on Education for Sustainable Development". It declared that education is one of the tools that ensure environmental protection and sustainable development of society. The world community has begun to talk more and more about the role of education in the transition of humanity to the principles of sustainable development. The UNECE Ministers of the Environment invited countries to include the concept of sustainable development in education

\footnotetext{
* Corresponding author: melnychenko.ruslana@gmail.com
} 
systems at all levels (preschool, secondary, higher); as well as in non-formal and out-of-school (extracurricular) education.

At the Eighth Conference of EEC Ministers of the Environment "Environment for Europe" (Batumi, 2016) it was stated that by 2030 it is necessary to achieve that all students acquire the knowledge and skills necessary for sustainable development, which will substantially enhance the relevant competence [4].

In general, in the European educational space, competence is defined as a dynamic combination of knowledge, skills, abilities, ways of thinking, personal qualities, attitudes and values, which determines a person's ability to successfully carry out professional and / or educational activities. Competences underlie the qualifications of graduates of higher education institutions (HEIs) [7; 28].

European researchers attach great importance to environmental competence. For example, Roczen proposed environmental competence model, which includes cognitive and motivational components. Thus, author examined the structure between different forms of environmental knowledge as well as connection with nature and ecological behavior [15]. Researcher identified the connection between human beings and nature as the motivational source of an individual's ecological behavior. This model conceptualizes environmental competence as the interlayer between connection with nature and ecological behavior promoting environmental knowledge. Therefore, the motivational source for ecological behavior is the connection with nature $[15 ; 16]$.

Frick and colleagues (2004) consider cognitive component the most important one. They distinguish three forms of environmental knowledge: 1) knowledge as a system (knowledge about nature and about environmental problems), 2) action-related knowledge (knowledge about ecological behaviors), and 3) knowledge about corresponding behavioral effectiveness [5]. Scientist claims that ecological behavior is induced by intellectual abilities [26]. However, whereas motivational dispositions strongly impact on ecological behavior $[15 ; 16]$.

According to Kumar and Rani, environmental education of teachers has a great importance [8], for it is an interdisciplinary subject. It can solve multiple environmental problems, which are faced by the humanity nowadays (global warming, pollution, greenhouse effect, ozone depletion etc.). The research results revealed that out of 600 trainees, $26.00 \%$ of teachers showed low level of environmental competencies; $45.33 \%$ of applicants possessed moderate level of corresponding competencies. Since teachers play key role in the environmental education, he/she is expected to possess substantial environmental knowledge, environmental awareness, positive environmental attitude and environmental competencies in order to achieve the objectives of environmental education. Therefore, teacher training institutions should take the accountability to organize orientation programs, refresher courses, seminars and workshops on environmental problems and their solution, conferences, which imply great increase in the teachers' qualification [8].

According to Ponomarenko et al, the work on students' environmental competence formation consists of three main stages: 1) environmental orientation formation; 2) environmental professional competence formation (duty, ability, and willingness to make practical decisions following environmental safety); 3) environmental responsibility formation (integral value that allows a person to live in harmony with nature, other people and himself) [12].

The concept of ecological competence of students is the subject of scientific research of many Ukrainian scientists. The issue of formation of ecological competence of university students of biological specialties was researched by Tytarenko [29]. Theoretical and practical issues of environmental training of college students, technical schools are revealed in the works of Hurenkova et al [9], Ridei [14], Rudyshyn [13], who devoted their works to analyzing and solving various issues of professional training of ecologists. The ecological competence of the future biology teacher is the subject of research of Melnychenko [10; 11], Homlya [6], Tsurul [27], [19] etc.

Most authors agree that ecological competence is a category related to environmental awareness, environmental education and culture, corresponding values and thinking. It is formed at the social and household level in different segments of the population and is a key competence of graduates of general secondary, specialized secondary, vocational and higher education.

Specialists in the sphere of ecological education and upbringing Pustovit et al. define the «ecological competence» as:

- the ability of the individual to make decisions and act with the least harm to the environment;

- ability to responsibly solve life situations, to subordinate the satisfaction of their needs to the principles of sustainable development;

- ability to apply environmental knowledge and experience in professional and life situations, guided by the priority of environmental values and non-pragmatic motivation to interact with the environment;

- awareness of personal involvement in environmental problems solution and responsibility for the environmental consequences of their own professional and domestic activities [13, p. 8].

For students of Natural Science Departments and some technical, engineering and economic specialties, ecological competence is an integral part of professional competence.

In particular, Tytarenko considers the environmental competence of biology students as "the ability to apply environmental knowledge and experience in professional and real-life situations, guided by the priority of environmental values, namely: awareness of personal involvement in environmental issues, responsibility for environmental consequences of their professional and home activities." [29].

Shapran claims that the ecological competence of a future biology teacher is a component of professional 
competence. Its level is manifested through professional and domestic activities, when the acquired environmental knowledge, skills, values, experience are actualized in the ability to make decisions and perform adequate actions, aware of their consequences for the environment [19].

Lukianova and Hurenkova also consider the environmental competence of college graduates as a component of their professional competence; an integral characteristic of business and personal qualities, which seems to "reflect" the level of knowledge, skills, experience necessary for professional activity, as well as the social and moral position of an individual [9].

I. Barna et al. emphasize that during the training of 101 specialty "Ecology" bachelors each student will be able to become a professional, expert in ecology, provided mastery of special and general competencies specified in the standard, including: the ability to assess the impact of man-made factors on the environment; to identify the environmental risks; to use of ICT(s) for environmental research; to inform the public about the state of environmental safety, etc. [1].

Karpenko et al. notes that the formation of ecology competence of future environmental specialists is aimed at the conscious use of acquired knowledge in practice; formation of a system of values, human attitude to the environment. The same authors accordingly link the ecological competence of students with several aspects: 1) the formation of a system of knowledge about the environment; 2) gaining practical experience in using knowledge to solve environmental problems at the local and regional levels; c) forecasting appropriate behavior, activities in the professional sphere and life; d) the need to communicate with nature, the desire to take a personal part in its restoration and preservation [7, p. 10].

A similar opinion concerning the ecologicalevolutionary worldview of an individual as a system of principles, views, knowledge, values, beliefs, practical actions that determine the understanding of the unity of social and natural environment is expressed by L. Rybalko, O. Topuzov, L. Velychko. The authors believe that the abovementioned worldview has three important components: intellectual (ecological and scientific-natural knowledge, competencies), emotionalvalue (caring for the environment, admiration for the beauty of nature), and activity (environmental, research, ecological-naturalistic work) [18, p. 3].

Summarizing the different scientific views and personal experience of training students of students of Natural Science Departments, we note that the formation of environmental competence is carried out during:

- realization of ecological education (ecologization of the content of professional disciplines, conducting environmentally friendly training and corresponding types of practice);

- organization of extracurricular eco-directed work (nature protection, naturalistic, research activity);

- use of interactive technologies, innovative methods and forms of organization of the educational process (trainings, projects, case studies, group work, information and communication technologies (ICTs), eco-oriented scientific selectives, etc.).
The aim of our article is to analyze the mechanisms of formation of ecological competence of bachelors of Natural Science Departments, including future chemists, biologists, ecologists, as well as teachers of natural science in the educational environment of the university.

\section{Materials and methods}

The material for the article was the curricula and educational programs for the training of specialists of the first (bachelor) level of higher education of three universities of Ukraine - Zhytomyr Ivan Franko State University, National Pedagogical Dragomanov University and Kherson State University. The following educational and professional bachelor programs were analyzed: specialty 091 "Biology", 101 "Ecology", 102 "Chemistry", 103 "Earth Sciences", 014.05 "Secondary education (Biology and Human Health)", 014.06 "Secondary education (Chemistry)", 014.07 "Secondary education (Geography)". Thus, the investigation was conducted from the point of view of the ecological (environmental) component of compulsory and variable educational components. Based on the analysis of the Standards of Higher Education, the program learning outcomes and competencies of the relevant specialties of various fields of knowledge on environmental orientation are highlighted.

While working with students of advanced training courses in the system of Institutes of Postgraduate Pedagogical Education of selected regions of Ukraine, namely Vinnytsia, Zhytomyr and Rivne, we conducted a survey of more than 200 teachers of natural sciences. With the help of questionnaires, the levels of formation of the main components of environmental competence in teachers were determined, the most effective forms and methods of their environmental work with students were identified.

During the implementation of Sorochynska Oksana's author's course "Training of future biology teacher for extracurricular ecological and naturalistic work with primary school students" a pedagogical experiment has been conducted for two years with the participation of about 400 students of the Faculty of Natural Sciences of Zhytomyr Ivan Franko State University.

\section{Results and discussion}

\subsection{Higher Education standards and programs analysis}

The importance of environmental knowledge, values, skills and corresponding competence at the professional level in the process of training of bachelors of natural sciences, biology and human health is recognized and supported at the state level in many countries, including Ukraine.

Thus, the Standard of Higher Education, specialty 091 "Biology" provides for the formation of two general (GC) and three special competencies (SC) of environmental orientation in students [21]: 
GC01. Ability to realize his/her rights and acknowledge responsibilities as a member of society, as well as to accept and implement the values of civil society and the need for its sustainable development, the rule of law, human and civil rights and freedoms in Ukraine;

GC09. The ability to act socially responsibly and consciously in order to preserve the natural environment;

SC06. Awareness of the need to preserve biodiversity, protect the environment and conduct rational and effective environmental management;

SC09. Ability to analyze the results of the interaction of biological systems at different levels of the organization, their role in the biosphere and the possibility of their use in different sectors of the economy, including biotechnology, medicine and environmental protection;

SC10. Ability to demonstrate knowledge of mechanisms for maintaining homeostasis of biological systems.

In addition, obtaining the bachelor level qualification of specialty 091 "Biology" in the system of higher education involves the formation of 7 program learning outcomes that contribute to the sustainable development of society and understanding of the relationship between man and the environment, namely:

$\checkmark$ Understanding of the social and economic consequences of the introduction of the latest inventions and scientific research results in the field of biology within the professional activities;

$\checkmark$ Demonstration of skills needed to assess unpredictable biological problems and make informed choices;

$\checkmark$ Application of models, methods and data of physics, chemistry, ecology, mathematics in the process of learning and professional activity;

$\checkmark$ Adherence to the provisions of biological ethics, rules of bio-safety and bio-protection in the process of training and professional activities;

$\checkmark$ Ability to predict the effectiveness and consequences of environmental protection measures;

$\checkmark$ Application of methods for determining the structural and functional characteristics of biological systems at different levels of their organization in practice;

$\checkmark$ Ability to analyze data on diverse living organisms [21].

The standard of higher education of specialty 102 "Chemistry" in addition to the general competence GC 01 provides for the formation of only one environmentally oriented program learning outcome: "Assess And Minimize Risks to the Environment While Carrying out Professional Activities" [24].

The standard of higher education of specialty 103 "Earth Sciences" in addition to the general competence GC 01 (see 091 "Biology") provides for the formation of only three professional (special) competencies related to sustainable development, namely: 1) knowledge and understanding of theoretical foundations of "Earth Sciences" as a complex natural system; 2) the ability to apply basic knowledge of physics, chemistry, biology, ecology, mathematics, information technology, etc. in the study of the Earth and its geospheres; 3 ) the ability to monitor natural processes [25].

The standard of higher education in the specialty 101 "Ecology" aims to develop such an integrated competence as the ability to solve complex specialized issues and practical problems in the field of ecology, environmental protection and sustainable use of nature. In the educational process the methods of environmental sciences are characterized by complexity and uncertainty of conditions" [22]. In addition to general competence, similar to the considered specialties, the standard provides for the formation of 13 special (professional) competencies and more than twenty program learning results in the field of ecology, environmental protection, environmental safety, environmental law, landscape management and biological diversity.

In the Draft Standard of Higher Education in the field of knowledge 01 Education / Pedagogy, specialty 014 "Secondary education (by subject specializations)" in 2017 very few competencies and program learning outcomes aimed at forming the ecological competence of the future teachers [23].

Thus, for the specialty 014.05 "Secondary education (Biology and human health)" there is only one professional competence declared (ability to understand and implement the strategy of sustainable development of mankind in the process of teaching the students) and one program learning outcome (ability to understand and characterize the strategy of sustainable development, as well as to reveal the essence of the relationship between the natural environment and a human being).

For the specialty 014.06 "Secondary education (Chemistry)" - no (!) learning outcomes or other corresponding educational results are associated with sustainable development and formation of ecological worldview.

The training of geography teachers is the most naturecentric and environmentally-oriented. Moreover, for future geographers of the specialty 014.07 "Secondary education (Geography)" the formation of two subject competencies and five learning outcomes is provided. For example, a student must be able to:

$\checkmark$ describe the main mechanisms of functioning of natural and social territorial complexes, their individual components, as well as to classify the links, dependencies and interrelations between them; to know the causes, results and consequences of the processes occurring in/between them;

$\checkmark$ explain the changes that occur in the geographical environment under the influence of natural and anthropogenic factors; formulate the consequences and determinants in the context of the concept of sustainable development of mankind;

$\checkmark$ characterize natural landscapes and regions, explain their features and interconnections formed by geographical location and other geo factors;

$\checkmark$ understand global socio-geographical processes, be able to compile characteristics of the world's population, sectors and spheres of the world economy;

$\checkmark$ to characterize and evaluate natural conditions and resources, population and economy of Ukraine, its role 
and place in socio-geographical processes of the modern world [23].

After conducting the analysis of bachelor degree education programs (240 ECTS credits, 30 hours each) and curricula of various higher education institutions that train specialists in the above-mentioned specialties of natural and educational fields, we confirmed low and medium percentage of environmental educational components in their composition (Fig. 1).

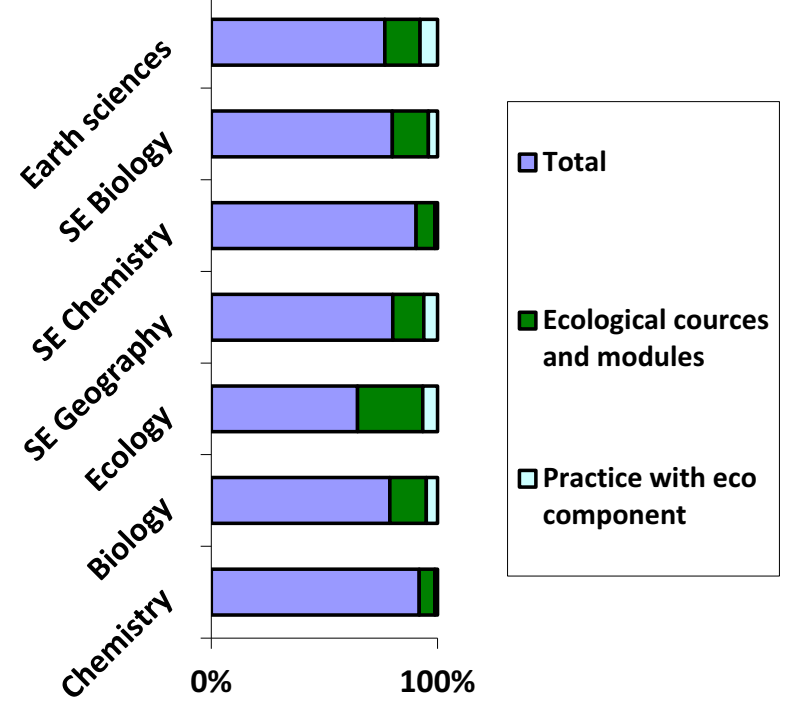

Fig. 1 Ecological (environmental) component of educational and professional programs (compulsory educational components), ECTS credits.

Thus, in the structure of the educational-professional program "Chemistry" at Zhytomyr Ivan Franko State University, the courses "General and Chemical Ecology" (3 credits), "Ecological Chemistry" (5 credits) are obligatory. In the curricula such courses as "Fundamentals of Chemical Technology" (6 credits), "Polymer Chemistry" (4 credits) contain separate topics aimed at developing the ecological worldview and competence of students. In addition, for several years in a row, among the selective educational components of the program students choose "Green Chemistry", "Environmental Chemistry", "Ecoanalytical Chemistry" courses.

In the educational-professional program "Biology" of the bachelor's level, the following subjects are obligatory for studying the discipline: "Bioethics and Biosafety" (4), "Ecology and Rational Use of Nature" (3). Some elements of ecological knowledge, including ideas about biodiversity, are given by the following courses: "Botany", "Zoology" (12.5 credits), "Microbiology" (5), "Soil Science" (3), "Biogeography" (4), "Plant Physiology" (5 credits), etc. Among the selective educational components, which are traditionally chosen by the majority of biology students, there are many that have an ecological focus ("Ecology and Ethology of Fish", "Systematics Of Chordates With The Basics of Ecology", "Systematics of Higher Plants with the Basics of Ecology", "Biomonitoring of Natural Waters").
For applicants studying in the educationalprofessional program "Secondary Education (Geography)" at Zhytomyr Ivan Franko State University the following disciplines are obligatory to master: "Environmental Safety and Sustainable Development" (5 credits), "Landscape Ecology" (4 credits), and also many courses containing semantic modules of ecological direction, including "Geography of Soils With Bases of Soil Science" (4,5 credits), "Economic and Social Geography of Ukraine" (5), "Meteorology and Climatology" (5,5), "Landscape Science" (4.5); "Fundamentals of Social Geography" (4), "Methods of Extracurricular Work in Geography" (5.5), "Regional Economic and Social Geography" (4), "Geography of the World Economy" (4 credits). In addition, future teachers of geography often choose such selective educational components as: "Regional Ecology", "Recreational Geography", "Ecological Foundations Of Nature" and others.

In the process of training of students of the same specialty at the National Pedagogical Dragomanov University and Kherson State University, the curriculum also provides for more than 40 credits of normative disciplines, similar to the above-mentioned, which include content modules of environmental orientation. Selective disciplines are focused on the formation of ecological competence "Anthropogenic Geomorphology", "Ecological Hydrology", "Management of Natural Resources" (3 credits each).

The Earth Science program at Kherson State University has significant potential for developing the environmental competencies of students. Thus, it includes compulsory educational components of the environmental professional competence and natural sciences, which contain environmentally oriented content of individual modules, namely: "Ecology" (3 credits), "Social Ecology" (3), "Life Safety and Environmental Safety" (3), "Environmental Monitoring" $(3,5)$, "Modeling and Forecasting of the Environment" $(3,5)$, "Organization of Ecological Management" (3), "Standardization of Anthropogenic Load on the Environment" (3), "Marine Geology and Geomorphology" (5), "General Geology" (3,5), "Meteorology and Climatology" (5), "Evolution of the Earth's Geospheres" (3), "General Hydrology and Oceanology" (4), "Landscape" (3), " Geography of soils with the basics of soil science " $(3,5)$. In addition, a significant part of the selective disciplines proposed for this specialty has an environmental focus: "Economics of Nature", "Rational Use of Natural Resources", "Recreational Geography", "Environmental Marketing", "Soil and Earth Protection" and others.

Formation of environmental competence of students of the educational program "Secondary education (Chemistry)" at National Pedagogical Dragomanov University is provided by a) normative disciplines: "Fundamentals of Chemical Safety" (6 credits), "Fundamentals of Production" (10), "Inorganic and Organic Toxicants" (6); b) disciplines of free choice of the student: "Environmental Chemistry" (6 credits) and "Modern Information Technologies in Ecological Chemistry" (4 credits). 
In the educational training program for the specialty 014.05 Secondary education (Biology and Human Health) of the National Pedagogical Dragomanov University and Kherson State University, the formation of environmental competence of applicants is carried out during the study of normative disciplines "Ecology" and "Biogeography" (3 credits). Some components of ecological knowledge form the normative courses, namely: "Botany", "Zoology" (11 credits), "Soil Science" (5), "Microbiology with the basics of virology" (4), "Plant Physiology" (5), "Evolutionary morphology" (3) and selective courses: "Plant Ecology", "Animal Ecology", "Dendrology", "Mycology", "Entomology” (3 credits each), "Animal Ethology", "Ecological and valeological training for health activities", "Biological systems" (4 credits each).

It is confirmed that the largest educational component of environmental orientation is the program "Ecology" for bachelors in all universities. So, at Zhytomyr Ivan Franko State University (ZIFSU) it includes 24 credits of educational and industrial practices, 3 credits of course works in various directions of ecology, 13 credits of educational courses containing modules of ecological direction, and also 94 credits for studying of various fundamental and applied ecological disciplines, among which there are: "Hydrology with the basics of hydroecology", "Bioindication of environmental quality", "General ecology", "Environmental monitoring", "Modeling and forecasting of the environment", "Ecosafety and technoecology", "Environmental legislation and environmental law", "Economics of Nature Management", "Landscape Ecology", "Reserved Business", "History of Ecology", "General Ecology and Neo-Ecology", "Organization of Management in Environmental Protection", "Formal and Informal Environmental Education", "Ecosystemology" and others. Among the elective educational components, students of ZIFSU mainly choose courses "Agroecology", "Bioindication of Aquatic and Terrestrial Ecosystems", "Ecological Tourism", "Ecotoxicology", "Ecophysiology of Animals", "Ecological Biotechnologies" and others.

Students of ecological specialties at Kherson State University and National Pedagogical Dragomanov University have a very similar "core" of the educational program, which contains more than 90 credits of environmental disciplines. These include courses similar to the Zhytomyr Ivan Franko State University program, as well as educational components such as: "Standardization of Anthropogenic Pressure on the Environment", "Environmental Impact Assessment", "Urban Ecology", "Environmental Inspection", "Environmental Entrepreneurship", "Environmental Marketing", "Environmental Policy", "Corporate Environmental and Social Responsibility", "Countering Climate Change", "Environmental Education and Science", etc.

Thus, the environmental education component is best expressed in the training of future bachelors of ecology (more than $50 \%$ of credits for the study of required courses and practices), which is related to their professional qualifications. In the training of future biologists, bachelors of Earth Sciences (geologists, hydrologists, organizers of nature management, etc.), teachers of geography, biology, environmentally oriented disciplines (or individual modules) and practice account for about $24-33 \%$ of the workload. Educational training programs for chemists and future high school chemistry teachers have the lowest percentage of educational components aimed at the formation of environmental competence - less than $10 \%$ of ECTS credits.

\subsection{Practical training as the means of forming students' ecological competence}

An important component of students training is practice and internships. We believe that they play a leading role in shaping the environmental competence of future biologists, chemists, ecologists and teachers of natural sciences.

During productive practice in laboratories, which is mainly conducted in natural and artificial ecosystems, there is process of verification of the received theoretical ecological knowledge and its transition to practical one, as well as the formation of awareness of its efficiency and reliability. The internship provides students with the data on regional environmental problems in combination with the acquisition of experience of interaction with nature; formation of corresponding skills, which contributes to the emergence of a professionally sufficient level of environmental competence of chemists, biologists, ecologists. In addition, the environmental competence of future teachers of biology, basics of health, science, geography and chemistry is a necessary condition for the formation of appropriate personality traits in students $[10 ; 11 ; 27]$.

Educational-professional training programs for students majoring in the specialties 102 "Chemistry" and 014.06 "Secondary education (Chemistry) provide practice in the basics of chemical production ( 3 credits), which must include analysis of environmental risks, environmental safety of a production, its impact on the environment.

Educational practices in zoology, botany, plant physiology and genetics ( 15 credits in total) at Zhytomyr Ivan Franko State University contribute to the formation of ecological competence of students majoring in 091 "Biology". They are held mainly in the spring and summer, combining laboratory classes with excursions to natural biocenoses, reserves, sanctuaries, botanical gardens, zoos and more. Similar teaching practices are provided by the National Pedagogical Dragomanov University for future biology teachers in accordance to the training programs, namely: botany, zoology (9 credits), soil science (1.5 credits) and biogeography (1.5 credits).

For students majoring in 014.07 "Secondary Education (Geography)" educational program at Zhytomyr Ivan Franko State University provides 24 credits of practice, 6 of which are focused on internships in educational institutions, and others have a professional aim and significant potential for the formation of environmental competence, namely the following ones: 
geology with the basics of geomorphology; soil science and landscape science; economic and social geography of Ukraine; i meteorology, climatology and cartography.

At the National Pedagogical Dragomanov University a similar set of practices for future geographers is also significant (12 credits included), namely it includes: complex (economic-geographical and physicalgeographical) and educational practice in meteorology and climatology; geology; hydrology; geomorphology; soil geography with basics of soil science; cartography with the basics of topography.

Training of students majoring in 101 "Ecology" provides 24 credits of practical training at Zhytomyr Ivan Franko State University (bachelor degree), which includes the following: general ecology (7.5), ecosystem (7.5), landscape ecology (3) and industrial practice (6). Training of ecologists at National Pedagogical Dragomanov University also has 24 credits of practical training, including industrial practice ( 9 credits) and four educational practices - general environmental (3), secondary environmental (6), environmental monitoring (3), technological (3 credits).

Educational (out-of-laboratory in-the-field) practices of biological, ecological, geographical directions can be considered one of the most effective forms of ecological education of students, for they ensure the formation of culture of nature, behavior in natural ecosystems, a responsible attitude to nature, including emotional perception and rethinking the origin of objects and phenomena of the environment.

We agree with the point of view of many researchers $[6 ; 17]$ concerning usefulness of undergoing the training practice of future biologists, ecologists, teachers of natural sciences in close proximity to the objects of nature, e.g. visiting reserves national parks, forests etc. to undergo However, only some of higher education institutions have stationary practice-oriented bases in protected areas. Thus, National Pedagogical Dragomanov University has a combined training and health complex in the Kolochava village on the territory of the Synevyr National Nature Park (Fig. 2). Uzhgorod National University's eco-training facility is located nearby, as well as the rehabilitation center for brown bears. Lake Synevyr Park also contains numerous natural monuments of regional importance where Red Book species of flora and fauna can be found (Fig. 3-5).

This ecological facility of national importance possesses a number of advantages, which are of a great importance for its use an outdoors educational base, including picturesque terrain, natural protection against environmental disasters, the availability of corresponding infrastructure which ensures satisfaction of all needs of the students in order to carry out effectively study of the fauna and flora of Transcarpathia, as well as possibility to monitor organized tourism and conduct environmental work in the national park, participate in the activities of the rehabilitation center for brown bears, while conducting research during internships. All this contributes to the formation of future natural sciences teachers' environmental competence and nature-centric worldview.

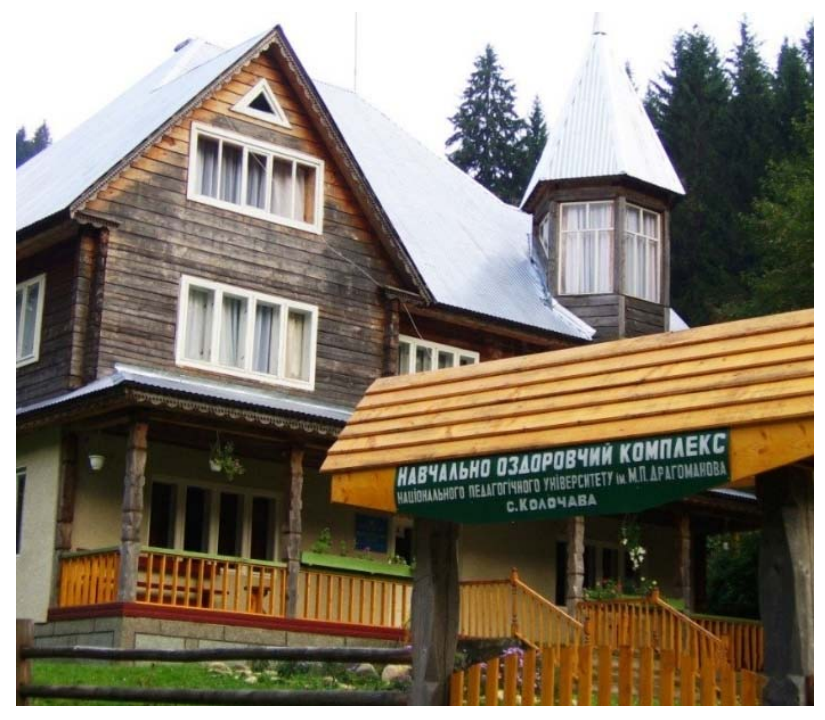

Fig. 2. Educational and health complex of National Pedagogical Dragomanov University, located in Kolochava village.

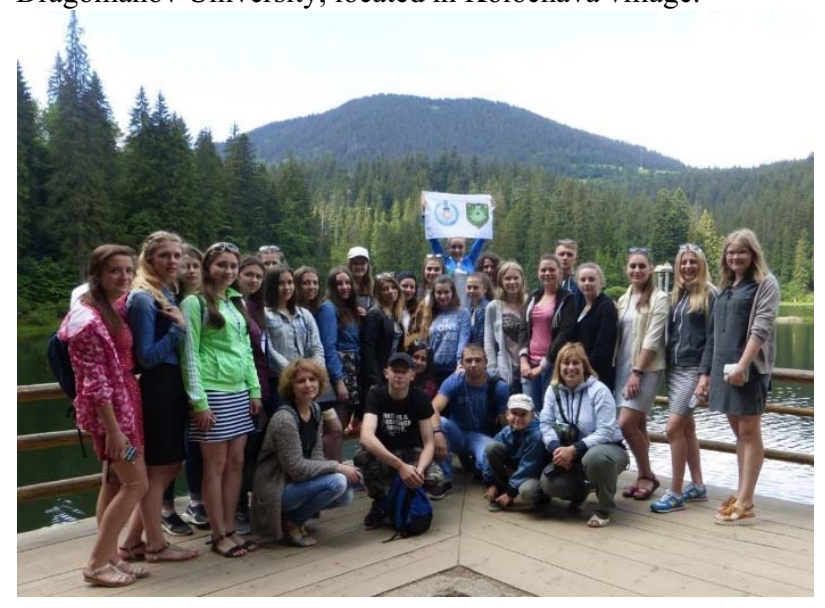

Fig. 3. Synevyr lake, biology students of Zhytomyr Ivan Franko State University during field practice.

Absence of property that may serve as the base for scientific or industrial practice makes it mandatory for the organization to conclude agreements on cooperation with other institutions of higher education (if such facilities are in their official possession), national parks, reserves or other corresponding legal entities. Combining several courses and / or several practices of one course (for example, botanical and zoological; zoology of invertebrates and chordates, etc.) is highly recommended. Therefore, practice leaders will get the necessary aid to effectively organize transportation, supplies provision, students' accommodation in order to carry out comprehensive environmental projects and conduct research. Students of the Faculty of Natural Sciences have the opportunity to undergo training and internships in Polissia, Drevlia, Rivne, Kaniv Nature Reserves, Synevyr National Nature Park through cooperation agreements with Zhytomyr Ivan Franko State University, which results in possibility to organize excursions to Shatsky lakes (Fig. 6, 7).

Natural science students and future teachers of biology and geography at Kherson State University are partially trained in the Askania-Nova Biosphere Reserve. 


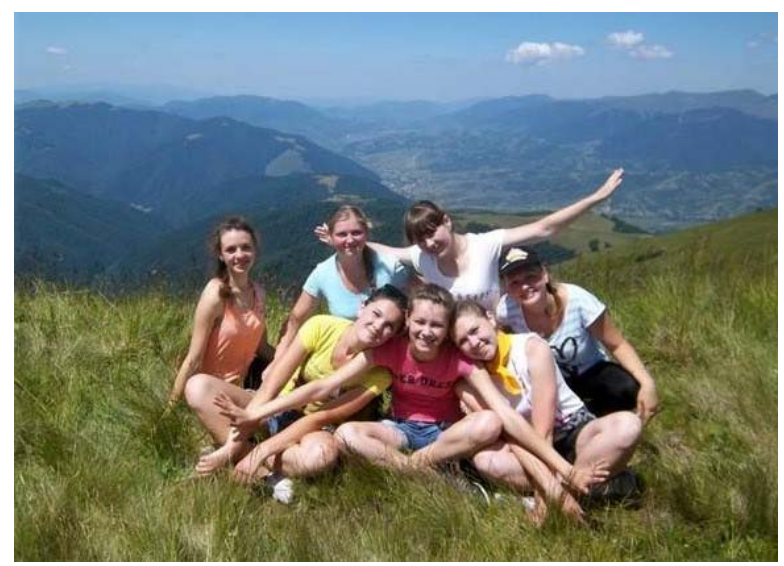

Fig. 4. Darvaika Mountain near Kolochava village, biology students of Zhytomyr Ivan Franko State University during zoology and botanic field practice.
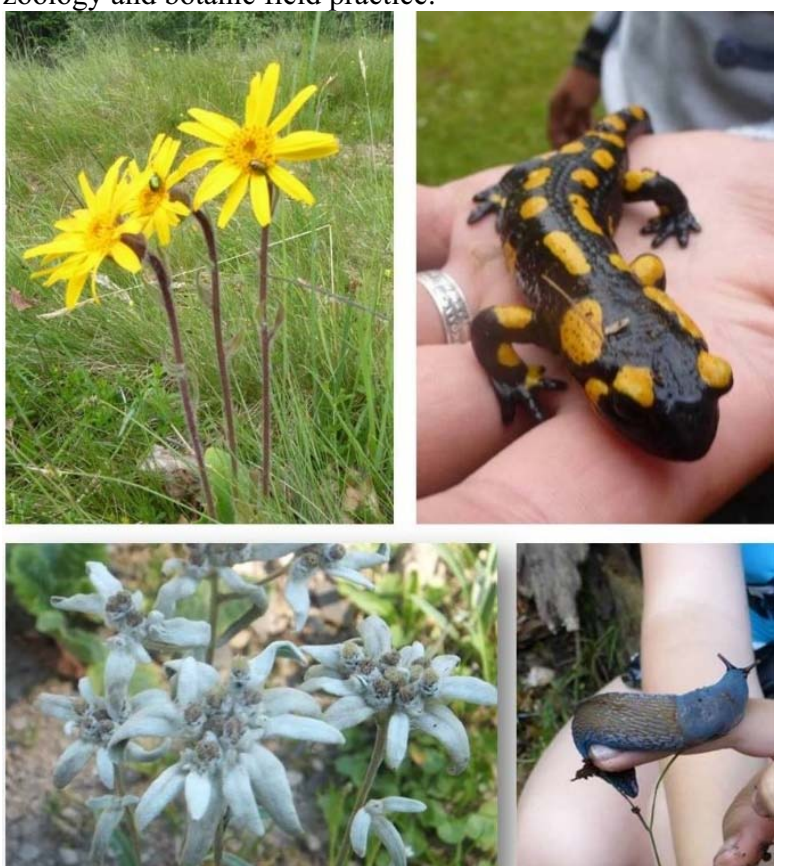

Fig. 5. Representatives of Transcarpathian Red Book flora and fauna species (students' photoreport).

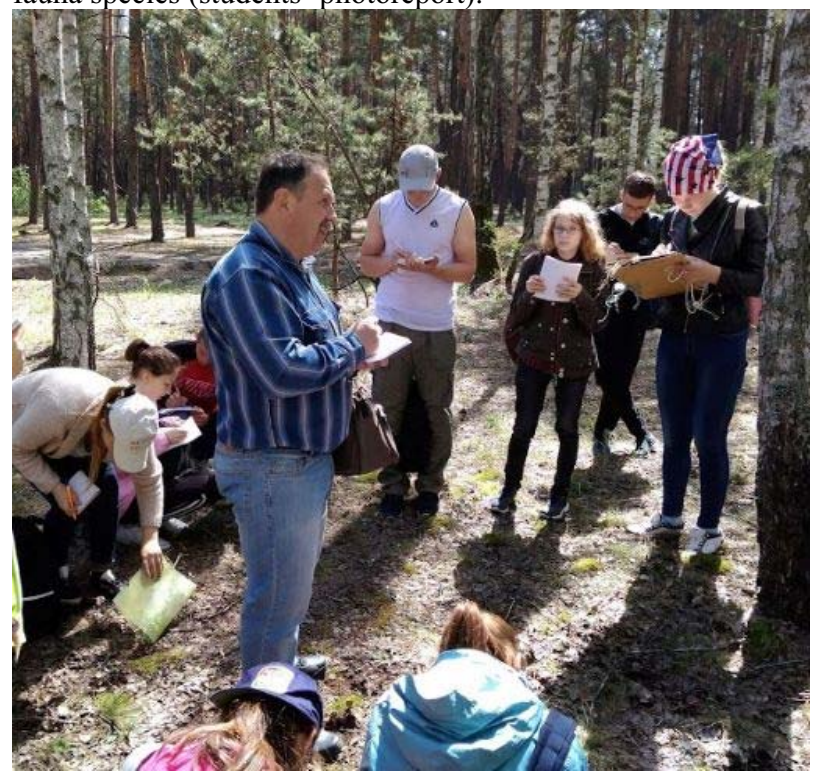

Fig. 6. Shatsky national nature reserve, ecology students (environmentalists) biology students of Zhytomyr Ivan Franko State University during practice.

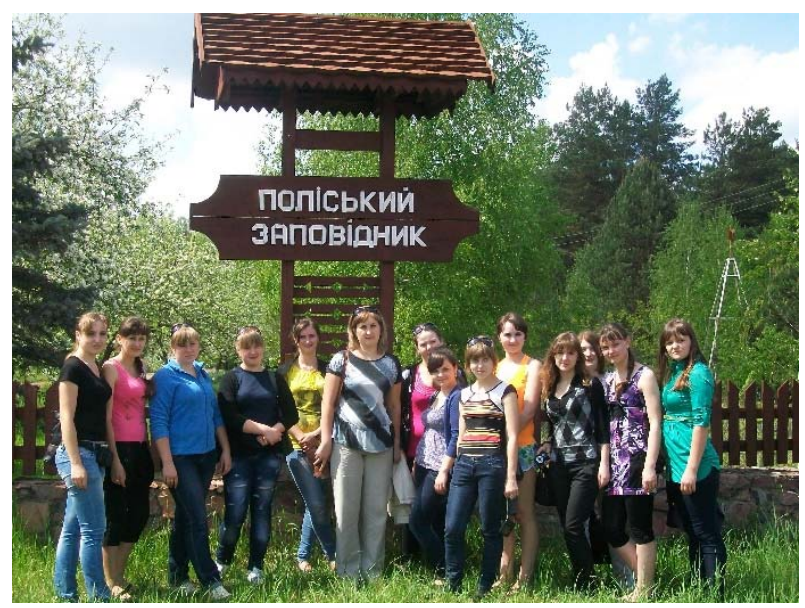

Fig. 7. Polissia Natural Reserve, biology students of Zhytomyr Ivan Franko State University during the practice.

\subsection{Students' field (out-of-laboratory) ecological-natural and research activities}

Involvement of students of natural specialties in the research, environmental and ecological-naturalistic work during extracurricular activities plays and important role in the formation of their environmental competence. Moreover, this is a characteristic feature of modern education in Europe [11]. In our opinion, ecological and naturalistic activity involves mastering environmental knowledge by students/pupils, as well as gaining experience in solving corresponding problems, which accustoms young people to the organization, implementation of practical environmental and research work, formation of ecological culture of personality, social experience, basic skills of horticulture, floriculture, forestry, etc.

Thus, students majoring in "Ecology" together with associate professor of ecology and geography department of Zhytomyr Ivan Franko State University Ivan Khomiak volunter to participate in the international project "Polissia - wildlife without borders". The aim of the project is to study and preserve the biodiversity of Polissia region as one of the largest natural landscapes in Europe. The project activities are implemented in such areas as: research and monitoring; expansion of existing and creation of new protected areas, improvement of their management; restoration of environments (unique wetlands); raising public awareness of the nature of Polissia; improving the welfare of the population of the territory in environmentally acceptable ways (https://wildpolesia.org/ukr/?fbclid=IwAR1069KDRH3 Zt2GJT9hlgRm9P7fX1GpjydSQQoAEoPD9Zzor09N90 $\underline{\mathrm{KHuCPI}}$ ). In particular, volunteers supported the initiative of the Ukrainian Society for the Protection of Birds to create a biosphere reserve under the UNESCO program "Man and the Biosphere" in the border areas with the Republic of Belarus, Zhytomyr and Rivne regions. Students of ecological specialties successfully competed with each other during the "Bird Day" campaign in team-based challenges, as well as monitored the nests of black storks Ciconia nigra in the Polissia Nature Reserve together with scientists. 
Students' participation in ecological forums, projects, and flashmobs proved to be quite effective ecologically oriented extracurricular work. For example, students of ecological specialties and the educators of the Faculty of Natural Sciences of ZIFSU joined the International Forum "Environmental Ambitions of Youth" (February 27, 2020, Kyiv, Verkhovna Rada).

Future chemists, ecologists, and biologists have repeatedly participated in the "Climate Collage" game, which was developed by Cedric Ringenbach in order to give young people a deep understanding of the relationships within the ecosystems and the impact of a human being on the environment. The game was first presented at the UN Climate Conference in Madrid in 2019 and since then it has been successfully used as an interactive method for the formation of environmental competence of young people.

They supported the international movement "Let's Do It, World", cleaning the historic part of the city of Zhytomyr, as well as participated in the "World Cleanup Day" flash mob (September 19, 2020) (Figs. 8-10).

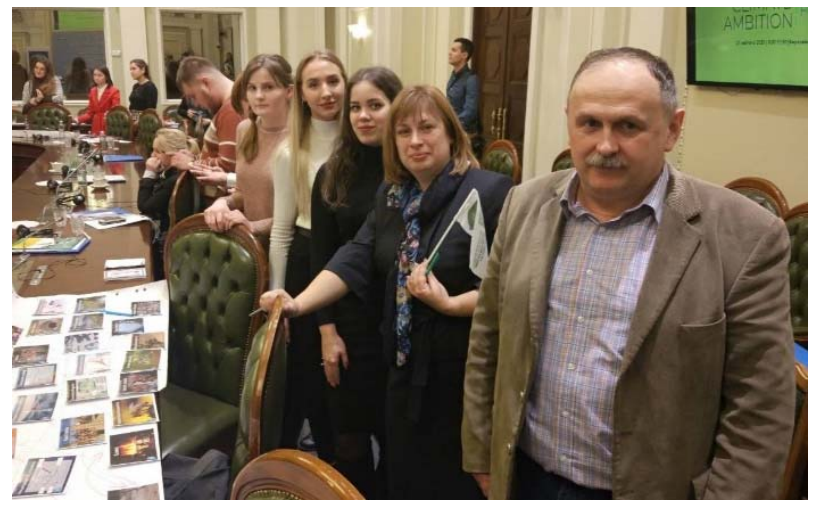

Fig. 8. Students and educators of ZIFSU visiting "Ecological Ambitions of the Youth" forum in the building of Verkhovna Rada of Ukraine.

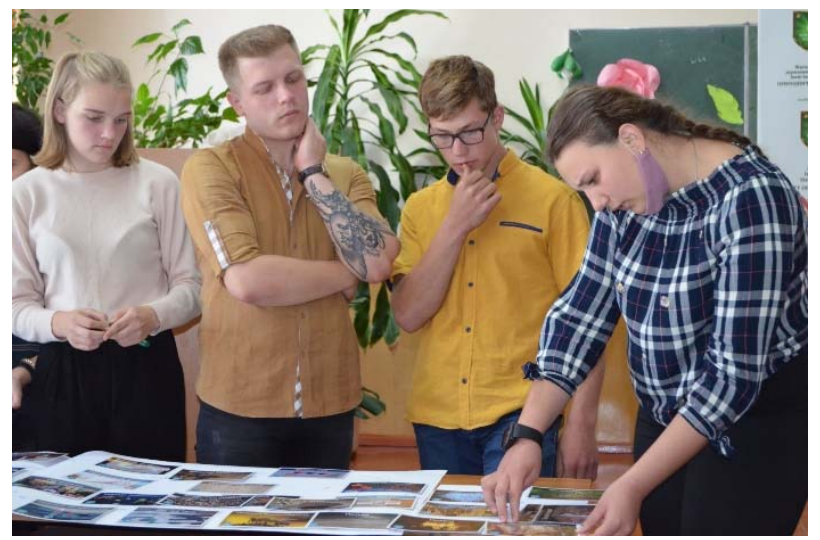

Fig. 9. "Ecological collage" game, faculty of natural sciences of ZIFSU.

The effectiveness of ecological and naturalistic work of young people is confirmed by research conducted in the framework of the introduction of university selective discipline "Methods of ecological and naturalistic activity in general schools and out-of-school educational facility" (National Pedagogical Dragomanov University, Olga Tsurul) [27] and the author's course "Training a future biology teacher for extracurricular environmental and naturalistic work with primary school students" (Zhytomyr Ivan Franko State University, Oksana Sorochynska) into the educational environment [20].

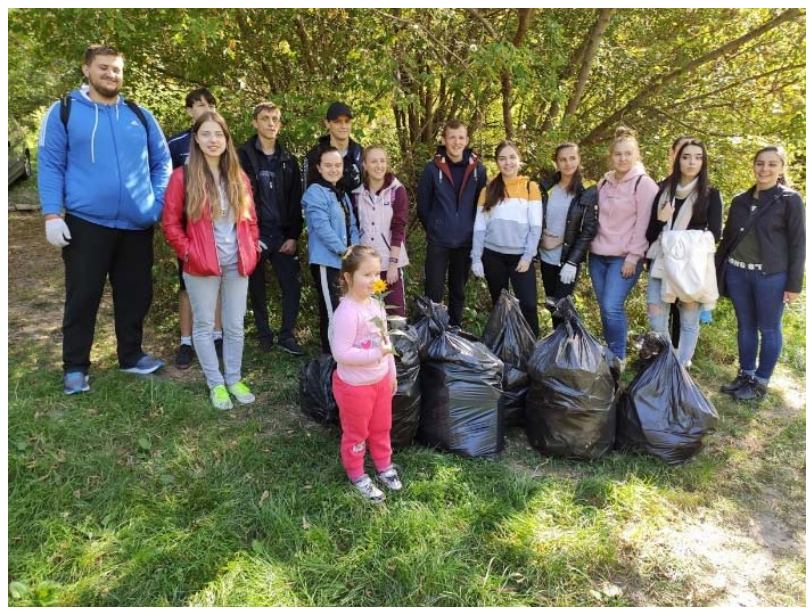

Fig. 10. Participants of «World Cleanup Day» campaign (Zhytomyr).

In particular, the program of the course "Training of future biology teachers for extracurricular ecological and naturalistic work with primary school students" provided for the introduction of traditional and innovative forms, methods of organizing ecological and naturalistic work into the educational process in order to improve the quality of formation of ecological competence of students, therefore an author's program, methodical recommendations and a manual "Ecological and naturalistic work at school" were developed and implemented. The author's program exploits such forms of work as a conference, development of an ecological project, ecological excursion and field hike, ecological expedition, ecological training, quest. Among the innovative methods used, there are the method of graphic and research works, business- and simulation games, dramatization games, case studies, interactive methods ("Fish Bowne", "Bloom's Cube", "Mental Map", "Brainstorming", etc.).

The experimental work lasted for 2 years and involved the ascertaining and forming stages of the experiment. At the initial stage, two groups of students were identified: control group (CG), which included 196 students, and experimental group (EG) with 198 participants.

To create a holistic picture of the formulated aim of the research, a survey was conducted, which allowed to identify a list of forms of ecological and naturalistic work. Prior to the implementation of the author's program, the level of students' awareness of the forms of such work was at a fairly low level. About half of the respondents mentioned forms of work that are theoretical in nature and have little effect on the formation of environmental competence (environmental exhibitions, holidays and competitions, writing essays, environmental campaigns, environmental-themed evenings and weeks, "What? Where? When?" intellectual club, CCS club, etc.). Only $19 \%$ of students noted the organization of environmental lectures and conferences, round tables; "blue" and "green" watch patrols, school forestry, 
ecological museums and theaters, ecological trails; performance of research and experimental works on school geographical and meteorological platforms, ecological laboratories research work; training and substantiating research projects.

However, in contrary to the students, teacherspractitioners from Zhytomyr, Vinnytsia and Rivne regions have given a particularly different statistical gradation of the effectiveness of applied forms of ecological-naturalistic work in the formation of ecological competence:

1) ecological excursions and expeditions $(58,7 \%)$,

2) ecological campaigns $(56,1 \%)$,

3) ecological trail experiments and observation $(54,8 \%)$,

4) eco-trainings $(53,5 \%)$,

5-6) empirical experience while working at the pet's corner or conducting a field research at the out-oflaboratory research site (по 49,6\%),

7) eco-scientific projects $(35,1 \%)$,

8) ecological contests $(19,8 \%)$,

9) ecological exhibitions (17,2\%),

$10)$ eco-fashion contests $(15,9 \%)$,

11) collecting eco-stuff, conducting eco-holidays, flashmobs etc. $(8,9 \%)$ [10].

The results of our survey of teachers of natural sciences correlate with the research of other scientists [20]. According to the data collected, the most effective forms of environmental activities at school are the following: preparation and substantiation of environmental projects (over 50\%), seminars and conferences $(42.3 \%)$; business- and role-playing games (36.5\%); organization of cooperative creative work and educational environmental activities related to certain international and state projects $(32.7 \%)$; implementation of research and exploration work, excursions, ecological trails $(26.9 \%$ each); conducting lessons on sustainable development and environmental issues (26\% ) [10].

However, teachers mostly introduce forms of theoretical work and to a lesser extent are engaged in research work, observations and experiments on the ecological trail, conducting ecological excursions and expeditions, practical work in wildlife and educational areas, training, which indicates an unfortunately low level of their empiric involvement (Fig. 11).

This fact can be explained and justified by the insufficient level of eco-oriented training during their studies at the universities, as well as lack of time, unwillingness to carry out the specified form of work, which result in general weakening of students' interest in learning.

The formation of students' environmental competence within the author's program was carried out on the basis of the developed model of preparation for ecological and naturalistic work. Identification of the level of environmental competence of students (initial, intermediate, high) was carried out according to 4 criteria (motivational-target, cognitive, practical, personalreflexive), which correspond to its structure. The generalization of the results of the experiment was conducted using the method of score scales, which allowed to calculate the level of formation of environmental competence of students and the dynamics of change [20].

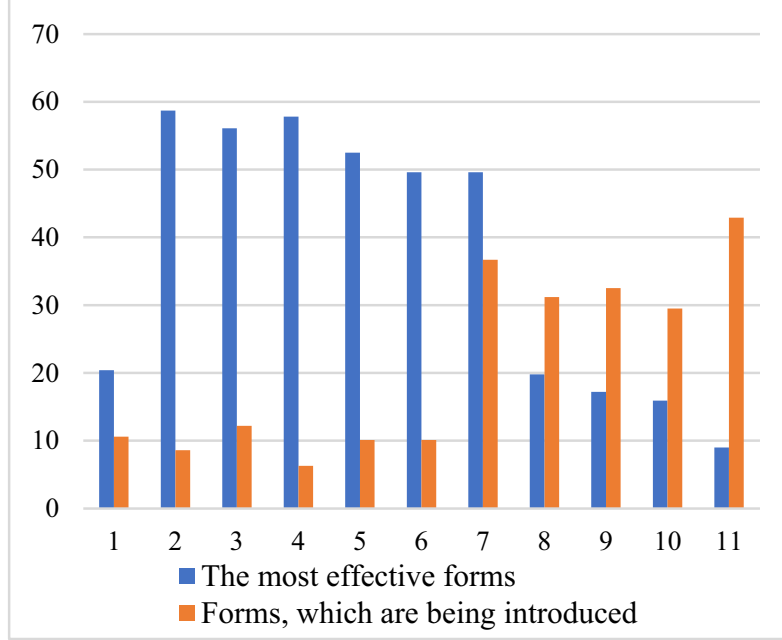

Fig. 11. Effective forms of environmental and naturalistic work that contribute to the formation of ecological competence of students (according to the results of a survey of teachers, \%).

Comparative results of identification of levels of formation of environmental competence on motivationaltarget criterion of control and experimental groups are specified in fig. 12 .

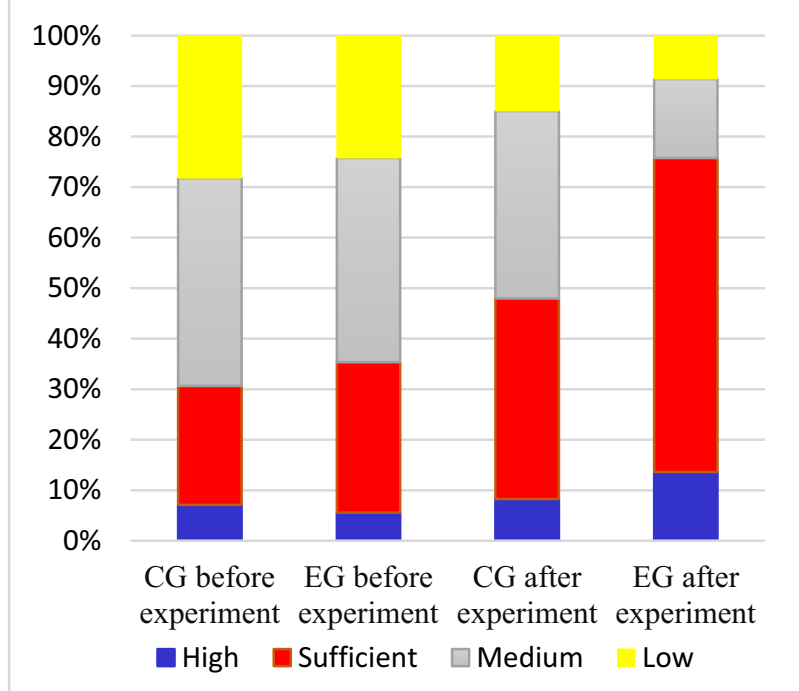

Fig. 12. Levels of formation of environmental competence of students on a value-motivational component according to results of experiment.

Cognitive component of the formation of environmental competence involved the gaining a set of knowledge (psychological-pedagogical, professionalenvironmental and naturalistic, methodological, organizational-methodological). Each of the knowledge groups contained a list of indicators for which the assessment was carried out.

The analysis of the results of the observational stage of the experiment showed a mostly low level of formation of students' ecological knowledge. Identifying the indicators of the cognitive component of the formation of environmental competence of students of control and experimental groups by cognitive criteria are shown in Fig. 13. 


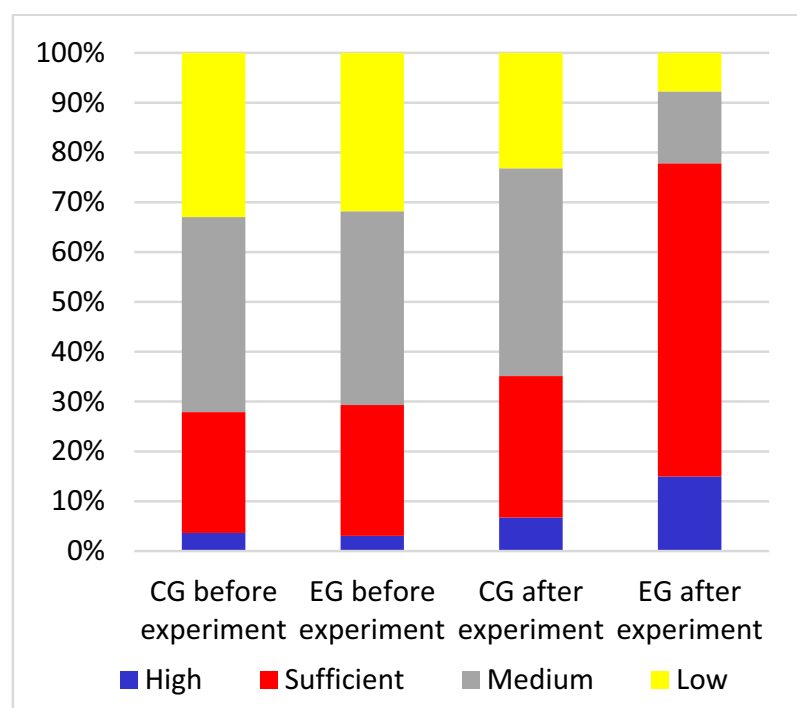

Fig. 13. Levels of formation of environmental competence of students on a cognitive component according to experimental results.

We observed significant changes in the results of cognitive component formation in the experimental group (EG) compared with the data of control group (CG). In particular, a high level of formation of environmental competence was shown by $14.66 \%$ of EG students, sufficient - $61.63 \%$, medium - $14.15 \%$, primary $-7.57 \%$. In turn, the distribution of CG students' answers was as follows: high level $-6.73 \%$, sufficient $28.38 \%$, medium -- $41.72 \%$, low $-23.16 \%$ (Fig. 13 ).

Practical (activity-based) component included such groups of skills as gnostic, designing, constructive, organizational, applied. Among the gnostic skills we singled out the following: the ability to conduct scientific research, monitor results of scientific activity, analyze scientific literature, etc. Designing skills are identified as the ability to: model forms and methods of ecological and naturalistic work; plan work and design the content of ecological and naturalistic work, etc. Constructive skills include the ability: to construct the content of ecological and naturalistic work, to introduce the most effective forms and methods; to have strategies for the formation of ecological competence, etc. Organizational skills are referred as the ability to carry out research activities; to manage the work of organizations of ecological and naturalistic orientation; to conduct ecological and naturalistic propaganda, and others. Practical (applied) skills are the application of methods of diagnosis of ecological and naturalistic abilities, organization of excursions, hikes, the ability to use ICTs, designing, modeling, etc. The level of ecological competence in the activity component was carried out on the basis of specially designed questionnaires, thus the reliability of the results was checked using the method of O. Smirnov, using Student's t-test. Indicators of the practical criterion after the introduction of the author's course differed significantly in the experimental group compared with the control (Fig. 14).

Personal-reflexive component of the formation of environmental competence of students involved the development of certain qualities and abilities (love of nature, erudition, diligence, perseverance, creativity, observation, environmental activity, etc.).

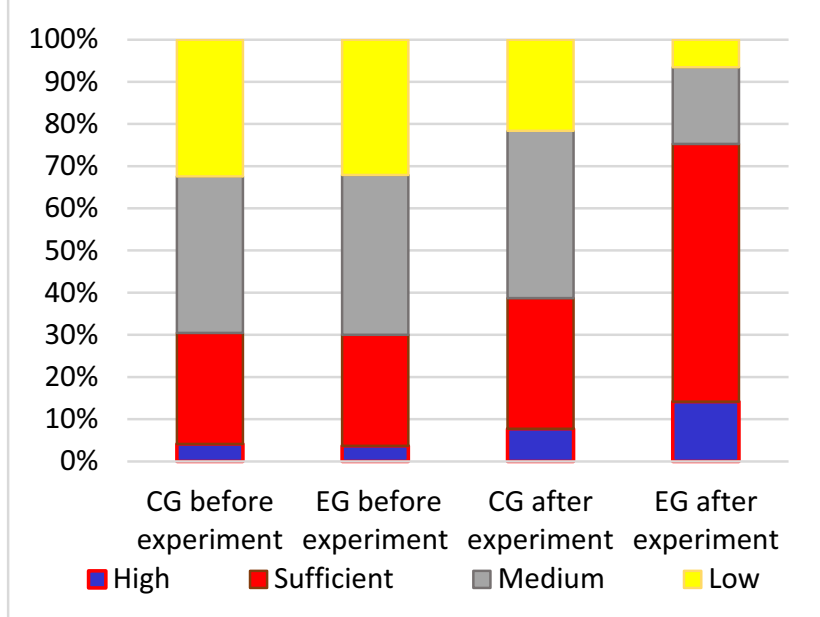

Fig. 14. Levels of formation of environmental competence of students on practical component according to the results of the experiment.

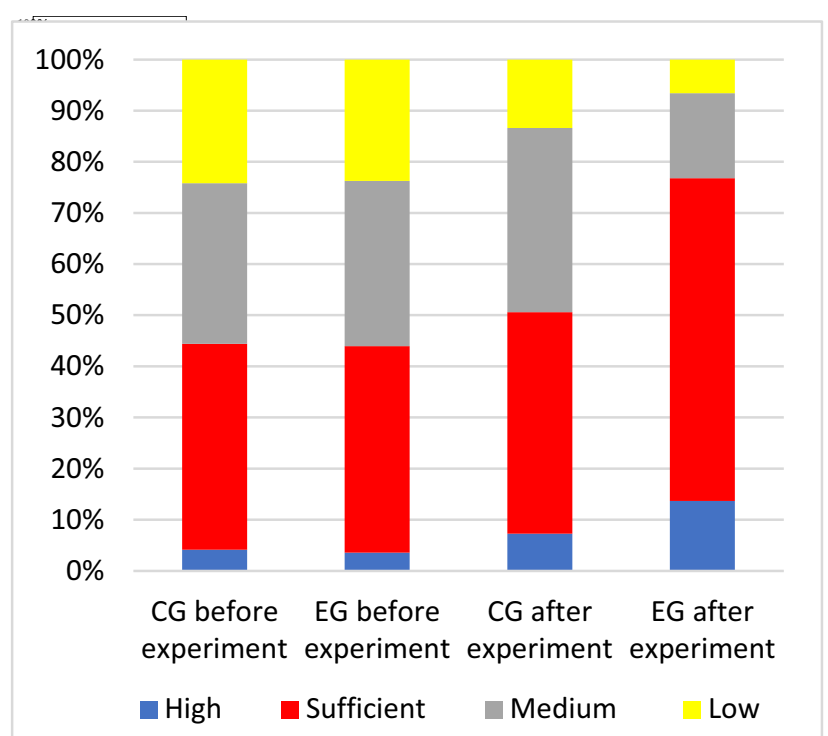

Fig. 15. Levels of formation of environmental competence of students on a personal-reflexive component according to results of experiment.

Analysis of the results of the formation of ecological competence in process of introduction of the author's program "Training of future biology teachers for extracurricular environmental and naturalistic work with primary school students" showed the effectiveness of its implementation in the educational process. After the formative stage of the experiment, the levels of environmental competence of students in the experimental groups were distributed as follows: high $15.03 \%$ of students; sufficient $-62.01 \%$ of respondents; medium $-16.66 \%$ of participants; low $-7.31 \%$. In the control group the indicators are: high level $-7.51 \%$, sufficient $-35.60 \%$, medium $-38.63 \%$, low $-18.27 \%$.

Thus, the generalized results of formation of environmental competence of students in experimental groups by results of ascertaining and forming stages of experiment show positive dynamics on all indicators and 
components (table 1, fig. 16) that testifies to efficiency of the introduced author's program.

Table 1. Dynamics of levels of environmental competence of students according to the results of the experiment.

\begin{tabular}{|c|c|c|c|c|c|c|}
\hline \multirow[b]{2}{*}{ 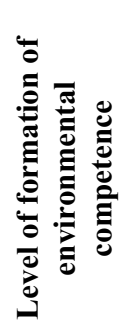 } & \multicolumn{3}{|c|}{$\begin{array}{c}\text { Control Groups } \\
\text { (CG) }\end{array}$} & \multicolumn{3}{|c|}{$\begin{array}{l}\text { Experimental } \\
\text { Groups (EG) }\end{array}$} \\
\hline & 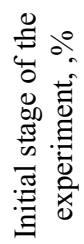 & 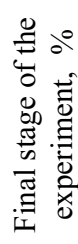 & 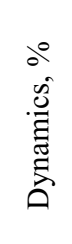 & 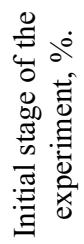 & 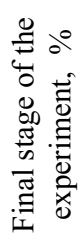 & 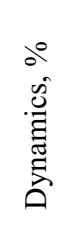 \\
\hline High & 4,5 & 7,5 & 3,0 & 3,9 & 14,0 & 10,1 \\
\hline Sufficient & 27,9 & 35,6 & 7,7 & 30,4 & 62,0 & 31,6 \\
\hline Medium & 35,9 & 38,6 & 2,7 & 37,5 & 16,7 & $\begin{array}{c}- \\
20,8\end{array}$ \\
\hline Low & 28,6 & 18,3 & ${ }^{-}$ & 28,2 & 7,3 & 20,8 \\
\hline
\end{tabular}

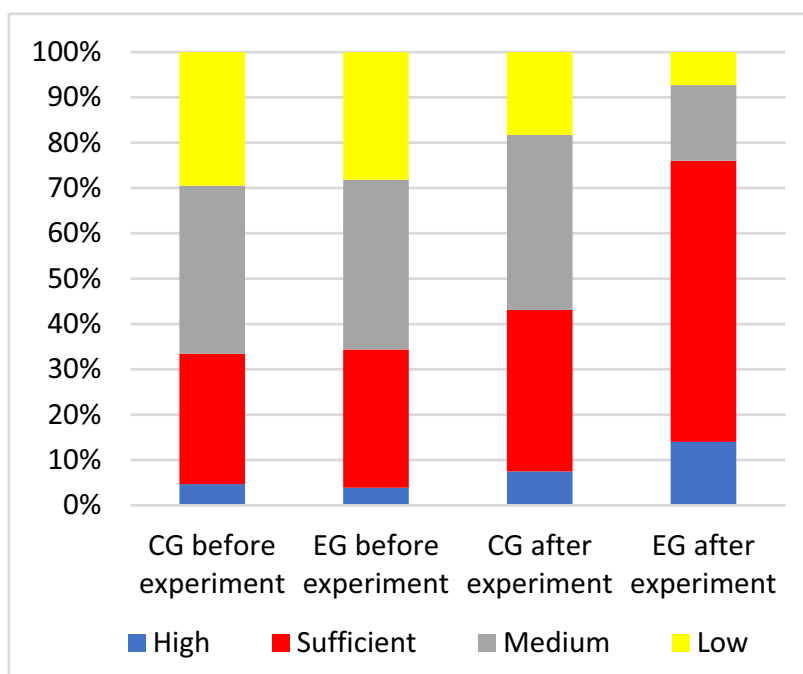

Fig. 16. Dynamics of levels of environmental competence of students according to the results of ascertaining and forming stages of experiment.

\section{Conclusions}

Thus, our research indicates that the need to implement the concept of sustainable development highlights the issues of formation of ecological (environmental) competence in students of natural sciences within the educational environment of the universities. In turn, the formation of environmental competence is carried out by acquiring environmental education through interactive technologies, innovative forms and methods of organizing the educational process, as well as during ecooriented extracurricular activities.

An analysis of the ecological education component of training of students of natural sciences confirmed the fact that its best manifestation is found in the content of education of future bachelors of ecology (over $50 \%$ of credits are directed to mastering the required courses and undergoing corresponding types of practice). In the process of training of future biologists, specialists in the field of Earth sciences, including teachers of geography and biology environmentally oriented disciplines (or individual modules) and practice account for about 24$33 \%$ of the entire workload. Educational training programs for chemists and future chemistry teachers have the lowest percentage of educational components aimed at the formation of environmental competence (less than $10 \%$ of ECTS credits), which significantly affects the level of formation of their ecological environmentally-oriented competence.

It is proved that the leading role in the formation of environmental competence of students of natural specialties is played by interactive practice-oriented forms and methods of teaching, as well as training and production practices, which is an essential component of their professional training.

The positive impact on the level of environmental competence development of students of natural specialties produces their involvement in research work, as well as active participation in environmental and ecological-naturalistic activities in extracurricular time, which is evidenced by the generalized results of the ascertaining and formative stages of our experiment.

The following fields are considered the most perspective for our further research: development and implementation of innovative technologies of extracurricular ecological and naturalistic work of students; finding theoretical and practical solution to the problem of integrating knowledge from different disciplines in the process of environmental education; analysis and implementation of foreign experience in the formation of environmental competence of youth; involvement of students of natural specialties in the activities eco-oriented associations for children and youth.

\section{References}

1. I. Barna, L. Hrytsak, and H. Henseruk. The use of information and communication technologies in training ecology students. E3S Web of Conferences, 166, $10027 \quad$ (2020). https://doi: $10.1051 /$ e3sconf/202016610027

2. Basic principles (strategy) of the state ecological policy of Ukraine for the period up to 2030 (Law of Ukraine of February 28, 2019 № 2697-VIII) https://zakon.rada.gov.ua/laws/show/2697-19\#n14

3. M. Diesendorf, C. Hamilton. Humen Economy: Ideas for an Ecollogically Sustainable Future, St Leonard Humen Ecology, Australia: Allen \& Unwin. (1997).

4. Eighth Environment for Europe Ministerial Conference Batumi, Georgia, 8-10 June 2016. Framework for the future implementation of the UNECE Strategy for Education for Sustainable Development.

https://www.unece.org/fileadmin/DAM/env/docum ents/2016/ece/ece.batumi.conf.2016.11.e.pdf 
5. J. Frick, F. G. Kaiser, M. Wilson, Environmental knowledge and conservation behavior: Exploring prevalence and structure in a representative sample. Personality and Individual Differences, 37, 15971613 (2004).

6. L. Homlia. Formuvannia ekolohichnoi kompetentnosti u studentiv biolohichnykh spetsialnostei u protsesi provedennia polovoi praktyky (Formation of ecological competence in students of biological specialties in the process of undergoing field practice). Vytoky pedahohichnoi maisternosti. 21. 39 - 43 (2018).

7. V. P. Karpenko, I. I. Mostoviak, T. M. PushkariovaBesdil. Otsiniuvannia sformovanosti ekolohichnykh kompetentnostei: navchalno-metodychnyi posibnyk (Assessment of the formation of environmental competencies: textbook) (Uman, UNUS, 2017).

8. P. N. Kumar, T. S. Rani A study on environmental competencies of teacher trainees. International Journal of Research and Analytical Reviews, Volume 5, I ISSUE 4 Oct.- Dec. 293-298 (2018).

9. L. B. Lukianova, O. V. Hurenkova. Ekolohichna kompetentnist maibutnikh fakhivtsiv: navch.-metod. posibnyk (Ecological competence of future specialists: textbook) (Kyiv-Nizhyn: PP Lysenko, 2008).

10. R. K. Melnychenko, V. V. Tanska. Ekolohichna kompetentnist vchytelia yak peredumova zdiisnennia neperervnoi ekolohichnoi osvity i vykhovannia (Ecological competence of the teacher as a prerequisite for the implementation of continuous ecological education and upbringing). Naukovi zapysky Kirovohradskoho derzhavnoho pedahohichnoho universytetu im. Vinnychenko. 4 (part 2) (Series: Problems of methods of physicalmathematical and technological education, 271-275 (2013).

11. R. Melnychenko, O. Sorochynska. Organization of specialized training and environmental activities of students in Eastern European countries (Development trends in pedagogical and psychological sciences: the experience of countries of Eastern Europe and prospects of Ukraine: monograph), Riga, Latvia: "Baltija Publishing”. 599 - 618 (2018).

12. Y. Ponomarenko, A. Yessaliev, R. Kenzhebekova, K. Moldabek, L. Larchekova, S. Dairbekov, L. Asambaeva. Students' Environmental Competence Formation as a Pedagogical Problem. International Journal of Environmental and Science Education, v. 11, 18, 11735-11750 (2016).

13. N. Pustosvit, O. Prutsiakova, L. Rudenko, O. Kolonkova. Formuvannia ekolohichnoi kompetentnosti shkoliariv: nauk.-metod. posibnyk (Formation of ecological competence of schoolchildren: teaching manual). Akademia pedahohichnykh nauk Ukrainy. (Kyiv: Pedahohichna dumka, 2008).
14. N. M. Ridei. Stupeneva pidhotovka maibutnikh ekolohiv: teoriia i praktyka: monohrafiia (Degree training of future ecologists: theory and practice: monograph) (Kherson: Oldi-plus, 2011).

15. N. Roczen, Environmental competence: the interplay between connection with nature and environmental knowledge in promoting ecological behavior. Technische Universiteit Eindhoven (2011). https://doi.org/10.6100/IR719557

16. N. Roczen, F. G. Kaiser \& F. X. Bogner. Leverage for sustainable change: Motivational sources behind ecological behavior. In V. Corral-Verdugo, C. H. Garcia-Cadena \& M. Frias-Armenta (Eds.), Psychological approaches to sustainability: Current trends in theory, research and practice, pp. 109-124 (2010).

17. S. Rudyshyn. Biolohichna pidhotovka maibutnikh ekolohiv: teoriia i praktyka: monohrafiia (Biological training of future ecologists: theory and practice: monograph) (Vinnytsia: Tempus, 2009).

18. L. Rybalko, O. Topuzov, L. Velychko. Natural science edition concept for sustainable development. E3S Web Conferences 166, $10030 \quad$ (2020) https://doi.org/10.1051/e3sconf/202016610030

19. Yu. P. Shapran. Ecological competence of future biology teachers: its essence and diagnostics. Zbiór raportów naukowych. ,, Postępy w nauce w ostatnich latach. Nowych rozwiazań. (28.12.2012 30.12.2012).Warszawa: Wydawca: Sp. z o.o.«Diamond trading tour», 29-39 (2012).

20. O. A. Sorochynska. Training of future biology teachers to extracurricular ecological and naturalistic work with pupils of secondary school (PhD Thesis), Zhytomyr: Zhytomyr State University named after Ivan Franko (2017).

21. Standard of higher education of Ukraine: first (bachelor's) level, field of knowledge 09 Biology, specialty 091 Biology. Order of the Ministry of Education and Science of Ukraine dated November 21, $2019 \quad$ № 1457. https://mon.gov.ua/storage/app/media/vishchaosvita/zatverdzeni\%20standarty/2019/11/22/201911-22-091-B.pdf

22. Standard of higher education of Ukraine: first (bachelor's) level, field of knowledge 10 Natural sciences, specialty 101 Ecology. Order of the Ministry of Education and Science of Ukraine dated 04.10.2018 № 1076 https://mon.gov.ua/storage/app/uploads/public/5bb/ 626/82a/5bb62682ac9f9819553374.pdf

23. Standard of higher education of Ukraine : first (bachelor's) level; the degree of higher education bachelor's degree. Field of knowledge 01 Education / Pedagogy, specialty 014 Secondary education (by subject specialties) (project, 2017) https://www.megu.edu.ua/wpcontent/uploads/2020/02/014-Sered.osv.bak..pdf

24. Standard of higher education of Ukraine: first (bachelor's) level, field of knowledge 10 Natural 
sciences, specialty 102 Chemistry. Order of the Ministry of Education and Science of Ukraine dated April 24, $2019 \quad$ № 563 https://mon.gov.ua/storage/app/media/vishchaosvita/zatverdzeni\%20standarty/2019/04/26/102khimiyabakalavr.pdf

25. Standard of higher education of Ukraine: first (bachelor's) level, field of knowledge 10 - Natural sciences, specialty 103. Earth sciences. Approved and put into effect by the order of the Ministry of Education and Science of Ukraine dated 24.05.2019 №730.

https://mon.gov.ua/storage/app/media/vishchaosvita/zatverdzeni $\% 20$ standarty/2019/05/28/103nauki-pro-zemlyu-bakalavr.pdf

26. Stern, P. C. Psychology and the science of humanenvironment interactions. American Psychologist, 55, 523-530 (2000).

27. O. A. Tsurul. Methodical training of future teachers of biology for implementation of contemporary objectives of environmental education and upbringing. The Scientific Issues of Ternopil Volodymyr Hnatiuk National Pedagogical University. Series: pedagogy, 1, 133 - 141 (2016).

28. Tuning Educational Structures in Europe. http://www.ehea.info/media.ehea.info/file/Tuning project/89/3/Tuning-Educational-StructuresEurope-executive-summary_575893.pdf

29. L. M. Tytarenko. Formation of ecological competence of students of biological specialties of university: the author's abstract of $\mathrm{PhD}$ dis. for science. degree of cand. of ped. science $(\mathrm{PhD}$ in Pedagogy): specialty 13.00.07 "Theory and methods of education", (Kyiv, 2007). 